University of Tartu

Faculty of Social Sciences

School of Economics and Business Administration

Triin Teppo

\title{
FACTORS ENCOURAGING THE CREATION OF SPIN- OFFS FROM STUDENT SATELLITE PROJECTS
}

\author{
Master's thesis
}

Supervisors: Research Fellow Eneli Kindsiko (PhD), Tõnis Eerme

Tartu 2019 
Allowed for defence on

(signature) Research Fellow Eneli Kindsiko (PhD)

Allowed for defence on

(signature) Tõnis Eerme

I have written this Master's thesis independently. All viewpoints of other authors, literary sources and data from elsewhere used for writing this paper have been referenced.

Author Triin Teppo 


\begin{abstract}
Student satellite projects are a widely used measure for introducing space technology industry to students as potential future workforce, entrepreneurs and innovators. This study presents factors encouraging the creation of space industry spin-offs from student satellite projects. Between April 2018 and June 2018, eight semi-structured interviews were conducted with the alumni of the student satellite project ESTCube-1 and Aalto Satellite Program (satellites Aalto-1 and Aalto-2), who started their own companies during or after their participation in these satellite projects. In this thesis, student entrepreneurship is being studied through the following factors previously outlined in university spin-off related research - assets related to intellectual property, knowledge and social capital, and additionally personal characteristics relevant to entrepreneurship. The results showed that the capabilities of student satellite projects depend on access to relevant human capital and the objectives of these projects. Currently the capabilities of these projects in terms of innovation and spin-off creation are limited. Nevertheless, by supporting the sustainable growth of student satellite projects, student's evolvement from being entrepreneurial to becoming entrepreneurs can encourage the creation of spin-offs, and therefore help along with supplementing the missing gap between student entrepreneurship and innovation in space technology industry.
\end{abstract}

Index terms: spin-off companies, innovations, academic entrepreneurship, space technology 


\section{Introduction}

Operations taking place in space are often characterised as risk-averse, conservative and highly demanding in terms of technical precision, leaving little room for risky innovative solutions, and emphasising the role of durability and stability (OECD, 2016, pp. 16-17). Nevertheless, recent technological developments have emphasised the role of innovation in space industry (OECD, 2016, p. 13). Among other factors, this has been brought along by technological advancements in the development of satellites and the evolvement of CubeSats (ibid.: p. 10). CubeSats are low-cost and small-sized satellites, initially developed to fulfil educational objectives - to introduce students with space technology (Poghosyan \& Golkar, 2017, pp. 79-80). The attractiveness of CubeSats stems from their cost and time related efficiency during development and launch (Poghosyan \& Golkar, 2017, p. 60; Buchen, 2015, p. 3). The standardised format used for CubeSats also means that launch service providers no longer have to depend on specific satellite manufacturers, which helps to reduce time and costs (Hevner , Holemans, Puig-Suari, \& Twiggs, 2011, p. 1). This has made CubeSats highly feasible for the industry of space technology development, and it has been acknowledged that CubeSats can also offer value for missions related to technology demonstration, science and space technology commercialisation (Poghosyan \& Golkar, 2017, p. 72; Sweeting, 2018, p. 352). Therefore, even though CubeSats are mainly used in education, they have also received wide attention in terms of other objectives in space technology industry.

Because of their rapid and cost-efficient development process, CubeSats are one of the most common tools used to introduce students with space technology development, especially in connection with building satellites (Sweeting, 2018, p. 352). In educational universities, these activities are most commonly implemented by carrying out student satellite projects. Student satellite projects are defined as a group activity used in universities, where people without prior training develop and manufacture a fully functional satellite primarily to learn space technology engineering and development (Swartwout \& Jayne, 2016, p. 2). Therefore, the main objective of student satellite projects is to provide education. Nevertheless, to meet the market demand for more advanced objectives beyond education and in terms of innovation, technical requirements for the manufacturing, development and overall operations of CubeSats increase, 
surpassing the requirements for operative student satellites implemented to fulfil educative objectives (Hevner, Holemans, Puig-Suari, \& Twiggs, 2011, p. 2). One of the main indicators for this is the size of CubeSats developed (Sweeting, 2018, p. 253; Hevner , Holemans, Puig-Suari, \& Twiggs, 2011, p. 2). Even though student satellites do not fulfil these goals yet, the increasing success rate of these satellites is encouraging, considering the capabilities that these projects could offer (Sweeting, 2018, p. 352). Therefore, innovation studies on CubeSats developed within student satellite projects are relevant.

Spin-offs, which are one of the main indicators helping industries grow innovation, have also received wide attention in the space sector (OECD, 2016, p. 12). In university setting, the effect of the transfer of knowledge from the faculty to students in terms of spin-off creation has been previously studied through the role of student involvement in science projects and working together with the faculty (Hayter C. , 2016, p. 486). These studies have highlighted the role of students on graduate or higher levels (ibid.). However, the creation of spin-offs from accumulated knowledge gained by students during their studies in the university has received less attention.

Student satellite projects are often implemented through the study method called ProjectBased Learning (PjBL) - group of students working together on ,real world” product development tasks (Donnelly \& Fitzmaurice, 2005, p. 88). PjBL type of projects are centred around the product and therefore product as an end-goal is also what directs planning, producing and evaluation of the project (ibid.). Because of their applied nature, PjBL projects have proved to be inspiring for students in terms of new ideas and encouraging the growth of innovation (Boh, De-Haan, \& Strom, 2016, p. 669). In connection with innovation upspring among students, previous studies have emphasised the importance of applied hands-on learning through directed entrepreneurial projects and courses (Hayter, Lubynsky, \& Maroulis, 2017, p. 1240; Boh, De-Haan, \& Strom, 2016, p. 667). Regrettably, there are only a few studies conducted on the value related to spinoff creation from $\mathrm{PjBL}$ projects that are primarily carried out to provide technology development education for students. This thesis is filling this gap by concentrating on student satellite projects and spin-off creation in space technology industry.

The aim of this thesis is to determine which factors encourage the creation of spin-offs from student satellite projects. The factors encouraging the creation of spin-offs are 
studied through three assets proved to support the creation of spin-offs - knowledge, social capital and intellectual property (Landry, Amara, \& Rherrad, 2006, p. 1601). The influence of these assets has been previously studied mainly among the academic staff of universities. In the theoretical part of this thesis, the impact of these assets among students participating in student technology projects is studied. The author also studies the personal characteristics of students as the prospective implementers of these assets. The following research questions are addressed in this thesis:

- How capable are student satellite projects in terms of the creation of spin-offs in space technology sector?

- How can the creation of university spin-offs from student satellite projects be encouraged?

The structure of this paper is outlined as follows. The introduction is followed by a literature review that has been divided into three parts - firstly, the definition and essence of spin-offs; secondly, the essence of student satellite projects; and thirdly, a framework of factors encouraging the creation of spin-offs. The methodology used is described in the third section. The fourth part contains the results of the study and the fifth part the discussion of the results. The last part comprises concluding remarks supplemented with future research directions and practical implications.

\section{Literature review}

\subsection{Student entrepreneurship}

This section outlines the essence of student entrepreneurship. The phenomenon of entrepreneurship has been defined by Baron (2007, p. 19) according to the studies of Shane and Venkataraman (2000, p. 218) as following:

\footnotetext{
"A filed of business that seeks to understand how opportunities to create something new (e.g. new products or services, new markets, new production processes and raw materials, new ways of organizing existing technology) arise and are discovered or created by specific persons, who then use various means to exploit or develop them, thus producing a wide range of effects."
} 
As this study is concentrating on encouraging factors of entrepreneurship, the emphasize will be put on general phenomenon of entrepreneurship and agents involved in venture creation, and less on the venture itself. From definition, the process of entrepreneurship has been related to the opportunity discovery, evaluation and exploitation, and people involved in the process as individuals who discover, evaluate and exploit new opportunities (Shane \& Venkataraman, 2000, p. 218). Previous research conducted on the encouragement of technology students' entrepreneurship has been mainly concentrated on the impact of entrepreneurship related programs. Related to the process, concentration has been put on two main process related to entrepreneurship. First, the more narrow process of becoming an entrepreneur, that has been related to keywords like opportunity recognition, business creation, managing and scaling and self-employment - creating value through the business venture creation (Lackeus, 2015, p. 9; Lilleväli \& Täks, 2017, p. 4). Secondly, broader definition of becoming entrepreneurial has been related to personal development, initiative taking, self-reliance and other aspects connected to personal growth (Lackeus, 2015, p. 9). Because of the extent of the knowledge emerging from higher education institutions and its impact on high-growth markets and innovation, the narrow approach has received wider attention (Vestergaard, 2015, p. 14). Nevertheless, both approaches are considered vital in terms of student's entrepreneurship.

One of the more widely used determinants in previous research to explore the context of innovation has been the implementation of spin-offs (Mathisen \& Rasmussen, 2019, p. 26). Spin-offs (or 'spinouts' as a less used synonym) are commonly referred to as a process or a result of that process where a new and separate business venture emerges from another entity (Cooper, 1971; Landry, Amara, \& Rherrad, 2006; Miranda, Chamarro, \& Rubio, 2018; Boh, De-Haan, \& Strom, 2016). In university context, spinoffs are often characterised as business ventures exploiting the commercialisation output for knowledge that has emerged from university research (Miranda, Chamarro, \& Rubio, 2018, p. 1008). The basis of this kind of knowledge exploitation is extensive scientific research hidden inside the university as a possible source for creating financial value to the university through commercialisation processes (Wood, 2011, p. 152). The importance of spin-offs for commercialisation purpose derives from the strategic advantage extensive research brings, i.e. creating a competitive advantage on the market (Landry, Amara, \& Rherrad, 2006, p. 1600; Mathisen \& Rasmussen, 2019, p. 27). 
Therefore, spin-offs are more common in high-tech industries and, as being involved in emerging markets, the need to be adaptable is emphasised (Mathisen \& Rasmussen, 2019, p. 27). This way, spin-offs have proved to provide a great platform for studying issues related to new venture growth (ibid.).

Because of the scientific environment, previous research has been mostly focused on the role of academic staff in terms of finding profitable outputs for their scientific work and the creation of spin-offs (Urbano \& Guerrero, 2013, p. 41; Vohora, Wright, \& Lockett, 2004, p. 147; Rao \& Mulloth, 2017, p. 10). Nevertheless, recent studies have also started to emphasise the critical role and extent of the number of students and alumni participating in the creation of spin-offs from universities (Åstebro, Bazzazian, \& Braguinsky, 2012; Boh, De-Haan, \& Strom, 2016). Spin-offs created by students are usually more concentrated on commercial value and less on the exploitation of scientific results, which usually makes the market entry more easily doable (Pirnay, Surlemont, \& Nlemvo, 2003, p. 358). As the commercialisation of space technology in the emerging high-tech market involves a high degree of novelty, it is vital to concentrate on two different angles of knowledge transfer.

In the process of spin-off creation from university research, postdoctoral and graduate students (later referred to as just students) have an extensive role in terms of convincing faculty members to establish spin-offs and providing the initial knowledge needed to support the newly established venture (Hayter C. , 2016, p. 486). Moreover, students support spin-off creation by contributing in the area of initial research needed for the spinoff (Hayter C. , 2016, p. 482). This means that they not only have a role in the operational side of the venture, but they also contribute to the outcome in terms of the product or service. The role of students involved in a spin-off also becomes more important over time and along with the growth of the spin-off. It has been found that the main interest for academic staff involved is to eventually step aside from the daily activities of the spinoff and refocus their attention to academic research, preferably retaining an advisory role in the company (Hayter C. , 2016, p. 486). Research has found that the success of spinoffs is linked to internal and external connections and resources available for students in the university (Hayter, Lubynsky, \& Maroulis, 2017, p. 1251). Nevertheless, most of the student spin-offs are based on knowledge gained from their studies, not from direct 
scientific results. This type of tacit knowledge accumulates among students during their studies and is more based on interaction with the faculty, and less on contractual relationship with the university (Pirnay, Surlemont, \& Nlemvo, 2003, p. 359). Therefore, in order to study the processes of student's entrepreneurship, the nature of knowledge that is being commercialized by students and the essence of the industry are important to consider. The relation has been outlined on Figure 1.

Figure 1. Determinants of entrepreneurship

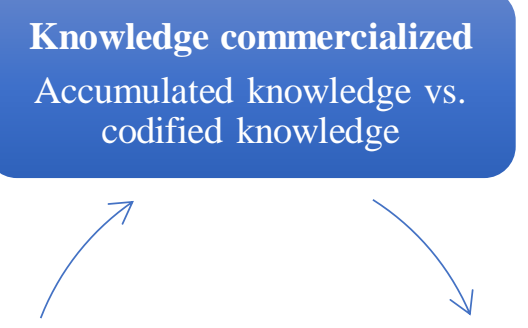

Process

Becoming entrepreneurial vs becoming an entrepreneur
Nature of the industry

more innovative vs. less innovative

Source: compiled by the author

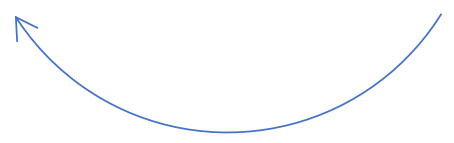

Previous research conducted on student entrepreneurship has mainly been concentrating on the impact of entrepreneurship related programmes implemented within the university in order to enhance entrepreneurial behaviour (Täks, Tynjälä, Toding, Kukemelk, \& Venesaar, 2014; Souitaris, Zerbinati, \& Al-Laham, 2007). The importance of these programs for students stems from two main aspects - the aspirational effect on student's intentions on choosing an entrepreneurship as a career choice and the presence of relevant resources helping with the establishment and the growth of the business venture (Täks et. al. 2014: p. 590; Souitaris et. al: p. 586). There has been less entrepreneurship education research conducted on practical learning related educational initiatives that are more concentrating on providing relevant education than aspiring educational behavior. However, as students themselves consider practical learning experience highly important 
in terms of encouraging entrepreneurial behavior, studies on the impact of project-based learning on entrepreneurship are important (Souitaris, Zerbinati, \& Al-Laham, 2007, p. 586). Following section will outline the important characteristics of student satellite projects.

\subsection{Student satellite projects}

Educational space technology projects provide students with a practical learning opportunity and, therefore, they also tend to be interdisciplinary in essence, also involving other skills such as the optimisation of resources, juridical knowledge, and human resource management in addition to technical knowledge (Sundaramoorthy \& Cervone, 2013, p. 13). University satellite projects are often referred to as student-built satellites, emphasising the students' role in that (Swartwout \& Jayne, 2016, p. 3). The main objective of a student satellite project is to train students to design artificial systems sent to space, to integrate different systems, and to lead the whole process - meaning that students are given control over the whole development process (ibid.). Thus, most student satellites aim to be educational in their essence (ibid.). With the chance to build a satellite, students are given an opportunity to implement knowledge gained from their university studies, and also to develop a new skillset through two main aspects - implementing knowledge gained from structural educational tools (i.e. lectures, study materials, etc.) and learning to solve practical problems through the implementation of the study method called Project-Based Learning (PjBL) (Straub, Marsh, \& Whalen, 2017, p. 24). Rodri'guez et al. (2015, lk 1324) have outlined the following main characteristics most common to PjBL projects implemented in student satellite projects:

- the projects are long-term, their duration covering a period of several terms;

- the projects are student-centred;

- the projects are based on collaborative team learning;

- the projects are applied in their essence;

- the projects have productive outcomes;

- the projects have an impact on skills like self-management, teamwork, leadership, time management, communication, and problem-solving;

- the projects involve the use of technology-based tools. 
As the main objective of student satellite projects is to provide education, the knowledge gained by students in the course of these projects is the accumulated knowledge obtained during their studies. To ensure innovation in the industry of space technology development, however, scientific knowledge is also highly relevant.

\subsection{Factors encouraging the creation of spin-offs from student satellite projects}

The theory of the resource-based view of the firm assumes that a company gains its competitive advantage on the market by deploying its idiosyncratic resources (Pisano, Teece, \& Shuen, 1997, p. 510; Barney, 1991, p. 101). Previous research has found that the availability of certain assets facilitates the creation of spin-off companies from the academic environment (Landry, Amara, \& Rherrad, 2006, p. 1601). In this study, the emphasis is placed on three types of asset groups outlined by Landry et al. (2006): intellectual property, knowledge and social capital related assets. The list of assets has been supplemented with personal characteristics, relevant to more entrepreneurial students.

\subsubsection{Personal assets and characteristics}

Personal assets are very important when it comes to spin-off creation. In spin-off enhancement related studies, research has emphasised the importance of previous personal experience in knowledge commercialisation. The more experienced academic staff members are in this area, the more likely they are to reengage in commercialisation activities (Landry, Amara, \& Rherrad, 2006, p. 1609; Marion, Dunlap, \& Friar, 2012, p. 413). Among students, the effect has been less relevant. Even though they usually do not possess previous commercialisation or entrepreneurial experience, it is not a factor that would hold them back from spin-off creation (Boh, De-Haan, \& Strom, 2016, p. 668). The valuable learning outcome is considered the main incentive - even if the creation of a venture is not successful, the learning experience itself is highly valued among students (ibid.). It has been found that, in addition to previous entrepreneurial experience, the personal characteristics of the founders can have a significant impact on spin-off formation from universities (Helm \& Mauroner, 2007, pp. 262-263). Among scientists, for example, entrepreneurial motivation and personal traits connected to the need for independence and achievements have been considered important aspects in terms of spin- 
off creation (ibid.). Therefore, previous entrepreneurial experience and relevant personal characteristics are important in the context of spin-off creation, but the purpose of these factors differs by founders.

\subsubsection{Knowledge related assets}

In order to enhance the possibilities for spin-off creation, universities should invest in research that carries a high degree of novelty (Landry 2006: 1612). According to resource-based theory, one of the main assets for spin-offs are experienced researchers and engineers with greater knowledge in the industry (Powers \& McDougall, 2005, p. 297; Rasmussen \& Wright, 2015, p. 788). Hiring world-class scientists requires time and effort and is expensive, which means that these assets are of high importance for creating a competitive advantage in the market and thereby supporting high-technology development (Powers \& McDougall, 2005, p. 297). High quality research at universities has also shown a positive effect on student entrepreneurship (Beyhan \& Findik, 2018, p. 1351). Students perceive this effect from a slightly different angle. The main advantage in this case is better access to recent scientific results, helping the students to identify most relevant problems and find sources for resolving them (ibid.). The real benefit of the extent of knowledge assets hidden in the university in terms of student entrepreneurship is the interaction taking place between the researcher and the student - the more this kind of knowledge reaches students, the more positive effect it has in terms of spin-off creation (ibid: 1366). The best means for distributing this type of knowledge are face-to-face interaction and learning-by-doing study methods (ibid.: 1351). The better the interaction between the scientist and students, the more it can help in terms of spin-off creation. Due to its nature, this aspect is also treated under the assets related to social capital.

As the study focuses on student satellite projects, the possibilities for implementing high quality research in student satellite projects is being studied. CubeSats are a form of nanosatellites made of multiple $10 \times 10 \times 10 \mathrm{~cm}^{3}$ units, each weighing about $1.5 \mathrm{~kg}$ (Sweeting, 2018, p. 351). CubeSats operate as a single unit or a combination of several $1 \mathrm{U}$ units (Poghosyan \& Golkar, 2017, p. 60). Most of the CubeSats developed for educational purposes are comprised of up to three one-unit cubes (from $1 \mathrm{U}$ to $3 \mathrm{U}$ CubeSats) (Hevner, Holemans, Puig-Suari, \& Twiggs, 2011, p. 2). This sort of standardisation, in terms of one-sized cubes, facilitates the development of satellites and 
satellite deployment systems in space, making the development thereof easier for satellite launch vehicle producers as they do not have to depend on specific satellite manufacturers (Poghosyan \& Golkar, 2017, p. 60). However, to carry out tasks for more advanced missions, CubeSats need to scale in terms of the number of $1 \mathrm{U}$ units involved or measurements (Sweeting, 2018, p. 353; Hevner , Holemans, Puig-Suari, \& Twiggs, 2011, p. 2). It has been found that $6 \mathrm{U}, 12 \mathrm{U}$ and $27 \mathrm{U}$, for example, or a constellation of CubeSats could add value by increasing performance as compared to smaller CubeSats, and reduce complexity and minimise costs as compared to larger satellites (Hevner, Holemans, PuigSuari, \& Twiggs, 2011, p. 3; Sweeting, 2018, p. 360). Therefore, CubeSats and the constellation of CubeSats can complete greater science missions (Sweeting, 2018, p. 360). The extent of innovation in the market of CubeSats depends on the size of the CubeSats involved.

The growth of innovation is also related to methods for developing the way CubeSats are being built. In the field of CubeSat development, three main methods are usually outlined.

1. Bespoke approach - the most widely used development method in student satellite projects, where the satellite is built from scratch (Straub, Marsh, \& Whalen, 2017, p. 40; 42). It means that satellites are constructed from commercial off-the-shelf (COTS) components (Dubos, 2010, p. 593). COTS components are mostly microelectronics widely available and used in different industries. Their value stems from the fact that it is possible to use high quality technology for a more cost-efficient price (Sweeting, 2018, p. 360). It has also been pointed out that using COTS components makes satellites adjustable for changes and, therefore, suitable for use in consecutive missions that are technologically different from one another (Straub, Marsh, \& Whalen, 2017, p. 42). Due to the utilisation of previously developed technologies, their technological life cycle has also been considered an advance, providing an attractive cost-efficient platform for innovating space technology (Sweeting, 2018, p. 360). On the other hand, the reliability of these components is considered one of their greatest deficiencies, as they were not initially developed for use in space (ibid.). 
2. Kit-based approach - satellite subsystems needed in the development process are in-bought, and not developed from zero (Karvinen, Tikka, \& Praks, 2015, p. 302). This is the best option for developing individual satellites and missions (Straub, Marsh, \& Whalen, 2017, p. 40). The availability of different kit-based subsystems means that satellites can be assembled from pre-constructed parts, which helps to spare time during the development process and, consequently, reduce the cost of the project (Karvinen, Tikka, \& Praks, 2015, p. 302). In order to comply with the objectives and the mission, however, these subsystems might need altering or redesign, which could increase the cost and extent of the development process (Straub, Marsh, \& Whalen, 2017, pp. 49-50; Karvinen, Tikka, \& Praks, 2015, p. 302).

3. Framework-based approach - a hybrid solution based on the bespoke and kitbased approach, where a framework is used to test new technologies with less risk (Berk, Straub, \& Whalen, 2013, p. 2).

The bespoke approach is the most widely used method in terms of educating students to build satellites, and it offers the greatest adaptability for building and testing new things. Using COTS components is also attractive for space technology industry, as it allows the use of new technologies with fair prices. Framework- and kit-based approaches, however, are more reliable and reduce the time spent on development.

\subsubsection{Intellectual property related assets}

Intellectual property ownership is the most common indicator used to measure entrepreneurial activities among academic staff (Landry, Amara, \& Rherrad, 2006, p. 1602). Nevertheless, there is no mutual understanding as to whom the intellectual property should belong to in order to encourage the creation of spin-offs. Studies involved in university spin-off creation incentives have mainly been concentrated on two approaches - intellectual property rights belonging to the university or the inventor. It has been found that the more efforts the academic staff make to protect their work, the greater the chance for launching a university spin-off (Landry, Amara, \& Rherrad, 2006, p. 1611). This means that researchers themselves must have the will and knowledge to exploit the commercial output of the results of their academic work, but, more often than 
not, academic staff does not have the personal traits needed for that (Goldfarb \& Henrekson, 2003, p. 655). Re-distribution of intellectual property ownership from academic staff to university creates incentives for the university to become involved in spin-off creation procedures, create an environment with relevant resources, and, therefore, encourage the creation of spin-offs (Goldfarb \& Henrekson, 2003, p. 655; Fini, Fu, Mathisen, Rasmussen, \& Wright, 2017, p. 379). Most of the studies used in this research have been concentrated on academic staff and scientists as the employees of universities. The effect has been less studied in terms of spin-off creation and the role of students in the matter.

As students become more involved in R\&D projects carried out in universities, issues concerning intellectual property policy also become more relevant (Sohn \& Han, 2019, p. 146). Research conducted with students to determine their preferences in terms of intellectual property ownership and spin-off creation has led to the conclusion that clear management of intellectual property and avoidance of conflicts is highly preferred among students, and failure to do that can be discouraging for students who wish to continue their research or the creation of spin-offs (Hayter, Lubynsky, \& Maroulis, 2017, pp. 12511252; Sohn \& Han, 2019, p. 147). A recent research conducted by Sohn and Han (2019: 146-147) found that students who find value in exploiting commercial output for their inventions and work are interested in keeping the intellectual property ownership to themselves. If students did not see any commercial output for their knowledge, they agreed that leaving the ownership to the university was the most reasonable thing to do. Nevertheless, both groups expected assistance from the university in terms of intellectual property management issues. In addition, latest intellectual property ownership theories have emphasised the role of open-source technologies, where technologies developed are publicly available for everyone interested in modifying, developing and selling the product (OSHWA, 2019; Li, Seering, Ramos, Yang, \& Wallace, 2017, p. 2). This approach motivates students to seek help and recognition from the open-source community, and to develop the best product available (Li, Seering, Ramos, Yang, \& Wallace, 2017, p. 7). Therefore, intellectual property protection in terms of spin-off encouragement has received wide attention in terms of the ownership of the technology. The most suitable measures implied, can also encourage the creation of spin-offs. 


\subsubsection{Social capital related assets}

The availability of social capital has been related to academic and non-academic contacts available for students within and outside the faculty (Hayter C. , 2016, pp. 483-484). These assets have shown positive effect on both, the creation and the further growth of spin-offs (Hayter, Lubynsky, \& Maroulis, 2017, p. 1251; Landry, Amara, \& Rherrad, 2006, p. 1609). Social capital related to contacts within the faculty and with fellow students is important for the establishment of spin-offs, as it offers support in terms of initial motivation and knowledge (Hayter C. , 2016, pp. 484, 486). Involving students in basic research helps them understand the fundamental scientific problems tackled in the industry, thereby paving the way to finding solutions to problems related to the establishment of spin-offs (ibid.). Consequently, the inclusiveness of the faculty is important in terms of spin-off creation. In more advanced phases of spin-off development, the importance of other resources provided by the university and external contacts also become more important, while the role of contacts within the faculty diminishes (Hayter C. , 2016, p. 481).

The importance of social capital also stems from aspects related to the nature of the industry and the knowledge shared within it. Traditionally, shared knowledge is defined within one academic discipline (La Regina, 2013, p. 1). Space, however, is one of the industries that is multi-disciplinary by its nature, meaning that, to grow and advance, it needs an input from different scientific fields (La Regina, 2013, p. 1). Student satellite projects are very interdisciplinary as they involve students from different technical and non-technical academic disciplines (La Regina, 2013, p. 4; Sundaramoorthy \& Cervone, 2013, p. 12). Therefore, the benefits of sharing knowledge within projects are not only related to becoming familiar with the aspects of other fields, but it also helps to learn more about integration processes and the main pain spots of other industries, which is especially important for technical fields (Straub, Marsh, \& Whalen, 2017, p. 27). Therefore, PjBL projects help to create and disseminate the knowledge needed through social capital within the project in order to lead to further advancements in space industry, and to enhance further commercialisation processes (Boh, De-Haan, \& Strom, 2016, p. $667)$. 
In terms of the encouragement of spin-off creation, personal characteristics of students do matter - students with more entrepreneurial features are more likely to develop spinoffs. Also, student satellites provide a good platform to enhance the creation of spin-offs. The multidisciplinary knowledge distributed across student satellite projects gives students an opportunity to learn satellite development in practice and is an important asset to encourage the creation of spin-offs among students. Regrettably, the capabilities of CubeSats developed within these projects are still scarce. Assets related to intellectual property protection and the encouragement of spin-off creation are mainly related to the transparency of these policies for students, which should be guaranteed by student satellite projects and universities. Assets related to social capital and wider networks are some of the main factors encouraging the creation of spin-offs.

\section{Methodology}

This study was conducted by using qualitative analysis which is one of the most common data analysis methods used in social interaction related studies, and helps to present results as well as to contribute into the creation of theory (Guba \& Lincoln, 2004, p. 3). The most common form of data analysis used in qualitative research is text analysis (Gibbs, 2007, p. 3) that was also used for this study. In the empirical part of the thesis, two logics for qualitative research were used - deductive and inductive qualitative analysis. Deductive qualitative research analysis is based on previous research, which is then revised and updated considering new data (Bryant \& Charmaz, 2019, p. 109). The empirical analysis is based on four main topic blocks studied in the theoretical part. As this topic has not received much attention in previous literature, the interviewer was open to any thoughts and ideas the interviewees had, allowing new insights to inductively emerge from the data. The discussion was led by the interviewer who asked specifying questions, but did not direct the interviewees, to be able to study what was considered encouraging for the creation of spin-offs. This also served as the basis for inductive analysis. Inductive qualitative research analysis is a logic where data collection is not restrained by previously conducted structures (Thomas, 2006, p. 238). Therefore, in this study interview analysis was done inductively, by exploring similar patterns within the interviewees, and then comparing them again with four give themes. The process of analysis is presented in Figure 1. 
Figure 2. Framework for analysis.

\begin{tabular}{|l|}
\hline Scientists \\
\hline Topics from \\
theory \\
related to \\
assets \\
encouraging \\
spin-off \\
creation by \\
scientists \\
\hline
\end{tabular}
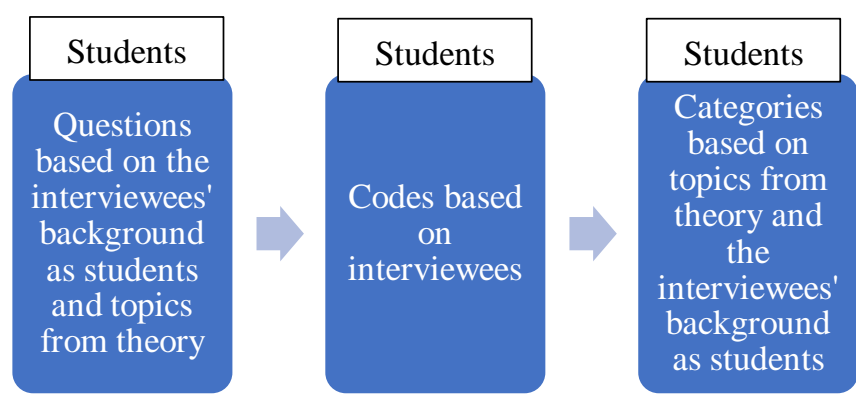

Students

Findings

based on

topics from

theory and

the

interviewees'

background

as students

Source: compiled by the author.

The interviewees involved in the research were chosen of the specific characteristics they entailed, and, therefore purposive sampling was used. As opposed to studies including random sampling, which includes samples of respondents and interviewees with diverse background, purposive sampling concentrates on a sample with similar characteristics and background (Etikan, S. A. Musa, \& Alkassim, 2016, p. 3). As the purpose of the thesis was to study the creation of spin-offs from student satellite projects, the sample involved in the thesis was formed of current active members and alumni of these projects, who participated in venture creation during or after being involved in satellite projects. This way, the sample chosen for the research comprised students with similar experience and traits of entrepreneurship, making the sample homogeneous (ibid.). Therefore, common characteristics of the sample involved in the study were the experience of being an active member in at least one student satellite project and creating a business venture during or after the end of the project.

Between April 2018 and June 2018, seven semi-structured interviews were conducted with eight alumni of the student satellite project ESTCube-1 and Aalto satellite program (satellites Aalto-1 and Aalto-2). All of them were face to face interviews, the shortest of them lasting 25 minutes, and the longest 1 hour and 32 minutes. The interviews resulted in a total of 75 pages of transcription. One of the interviews involved two respondents at the same time. The background of the students was an important part of the research. Previous research on the theory of spin-off creation has mostly concentrated on the academic staff of universities. The emphasis of the study was placed more on the members of student satellite projects and less on the ventures created. In terms of 
knowledge commercialisation, it is important to mention that only two spin-offs had to undertake activities related to intellectual property protection when establishing the company. Other spin-offs commercialised accumulated knowledge.

All of the members interviewed had technical tasks to fulfil during satellite projects. Four interviewees have founded two or more companies during or after their involvement in student satellite projects. One of the interviewees was not a founding member of the company, but one of its first employees. The sample also included one student satellite project manager who was a founder in one venture and a supervisor in another one. Only two interviewees became involved directly through their work, one as a founding member of one of the satellite projects, and the second one as a side-project for his workplace. Most of the founders were students at the time, and they mentioned that the main reason for joining student satellite development was the possibility to do something interesting in their field of interest and combine it with their studies. Two of the interviewees mentioned their previous limited experience in radio communications gained while serving time in the military, which led to their interest towards joining student satellite projects. One of the interviewees pointed out that he was initially interested in aviation, and its close relations with space industry guided him to join a student satellite project. None of the interviewees had commercialisation or entrepreneurship experience before joining the satellite project.

Table 1. Interviewees involved in the study

\begin{tabular}{|c|c|c|c|}
\hline PARTICIPANT & $\begin{array}{c}\text { ROLE IN THE SATELLITE } \\
\text { PROJECT }\end{array}$ & SATELLITE PROJECT & $\begin{array}{c}\text { DURATION OF THE } \\
\text { INTERVIEW }\end{array}$ \\
\hline $\mathrm{A}$ & Student & ESTCube/Aalto & $36 \mathrm{~min}$ \\
\hline $\mathrm{B}$ & Manager & Aalto & $31 \mathrm{~min}$ \\
\hline $\mathrm{C}$ & Member (enthusiast) & ESTCube & $25 \mathrm{~min}$ \\
\hline $\mathrm{D}$ & Student & ESTCube & $1 \mathrm{~h} 23 \mathrm{~min}$ \\
\hline $\mathrm{E}$ & Student & Aalto & $46 \mathrm{~min}$ \\
\hline $\mathrm{F}$ & Student & Aalto & $46 \mathrm{~min}$ \\
\hline $\mathrm{G}$ & Student & ESTCube & $53 \mathrm{~min}$ \\
\hline $\mathrm{E}$ & N/A & N/A & $1 \mathrm{~h} 36 \mathrm{~min}$ \\
\hline
\end{tabular}

Source: compiled by the author 
The analysis part of the thesis was based on four main topics which were outlined in the theoretical part. These four main topics were also considered the basis for carrying out the main coding of interviews. These codes were then divided into categories representing the findings of the study. Factors encouraging the growth of spin-off creation are discussed under each category. The coding itself based on the interviewees and the categories were conducted from similar patterns outlining from the interviewees. The findings of the analysis can be found in Table 2 .

Table 2. Codes and categories based on interviews

\begin{tabular}{|c|c|c|}
\hline ASSETS & CODES & CATEGORIES \\
\hline \multirow{14}{*}{$\begin{array}{c}\text { PERSONAL ASSETS AND } \\
\text { CHARACTERISTICS }\end{array}$} & Determination & \multirow{5}{*}{ Personal characteristics } \\
\hline & Self-awareness in daily tasks & \\
\hline & Self-motivation & \\
\hline & Readiness to observe knowledge & \\
\hline & Taking risks & \\
\hline & Project managing tasks/leading roles & \multirow{4}{*}{ Student's role in the project } \\
\hline & Proactivity & \\
\hline & Entrepreneurial experience & \\
\hline & Wider understanding of the technology & \\
\hline & Teaching how to raise hypotheses & \multirow{5}{*}{$\begin{array}{l}\text { Organisation's role in } \\
\text { student's personal growth }\end{array}$} \\
\hline & Providing guidance to get things done & \\
\hline & Freedom & \\
\hline & Enhancement of independence & \\
\hline & $\begin{array}{l}\text { Providing guidance to encourage the } \\
\text { execution of good ideas }\end{array}$ & \\
\hline \multirow{10}{*}{$\begin{array}{c}\text { KNOWLEDGE RELATED } \\
\text { ASSETS }\end{array}$} & Providing education & \multirow{6}{*}{ Project objectives } \\
\hline & Technological capabilities & \\
\hline & Technological development methods & \\
\hline & Development process & \\
\hline & Extensive time & \\
\hline & $\begin{array}{l}\text { Recognition of pain points in the } \\
\text { industry }\end{array}$ & \\
\hline & Student's limited knowledge & \multirow{4}{*}{ Human capital } \\
\hline & $\begin{array}{l}\text { Time period of student's involvement } \\
\text { in the project }\end{array}$ & \\
\hline & $\begin{array}{l}\text { Critical mass of space technology } \\
\text { specialists }\end{array}$ & \\
\hline & Continuing growth of projects & \\
\hline \multirow{7}{*}{$\begin{array}{l}\text { INTELLECTUAL PROPERTY } \\
\text { RELATED ASSETS }\end{array}$} & Conflicts & \multirow{3}{*}{ Transparency of IP protection } \\
\hline & Awareness of rights & \\
\hline & $\begin{array}{l}\begin{array}{l}\text { Transparency } \\
\text { university }\end{array} \\
\text { guaranteed by the } \\
\end{array}$ & \\
\hline & Open innovation & \multirow{4}{*}{ Ownership of IP } \\
\hline & Supporting innovation & \\
\hline & $\begin{array}{l}\text { No one should have the right to hinder } \\
\text { the execution of good ideas }\end{array}$ & \\
\hline & Favouring spin-off creation & \\
\hline \multirow{4}{*}{ SOCIAL CAPITAL ASSETS } & Multi-disciplinary knowledge & \multirow{2}{*}{ Interdisciplinarity } \\
\hline & Social contacts & \\
\hline & Acknowledgement & \multirow{2}{*}{ Support from the university } \\
\hline & Business related knowledge & \\
\hline
\end{tabular}




\section{Findings}

In the following section, categories resulting from the analysis are discussed under four main topics outlined in the theoretical part. These are also summarised in Figure 2.

Figure 2. Categories related to interview topics
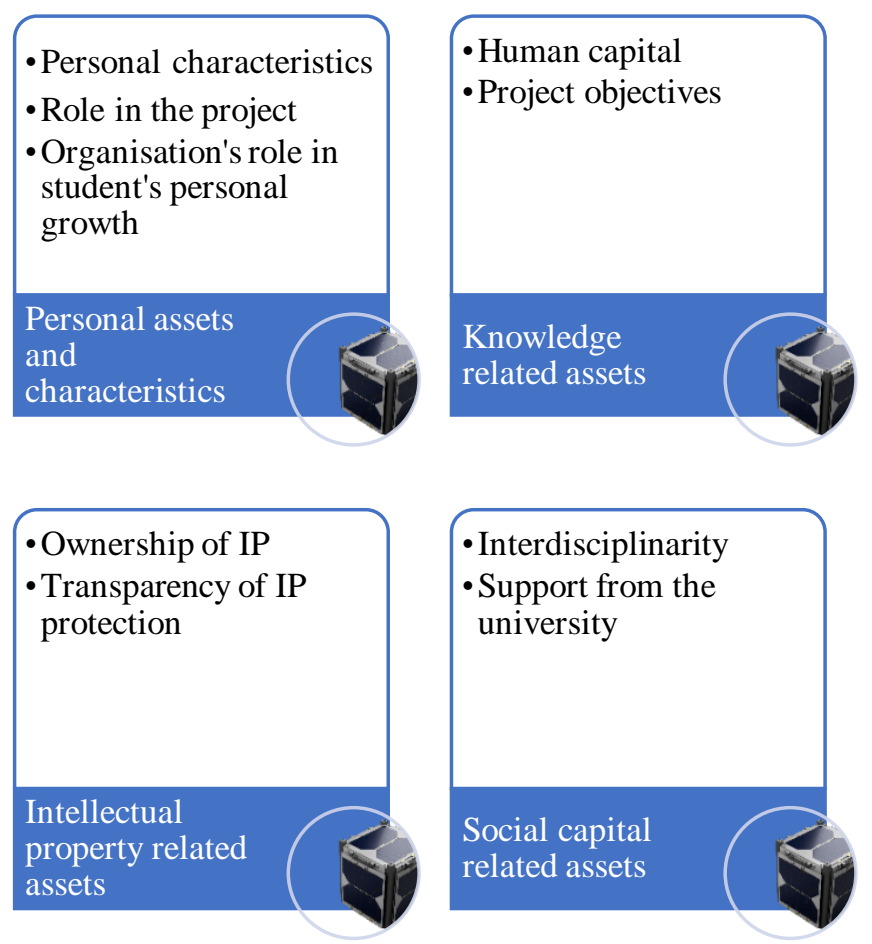

Source: compiled by the author

\subsection{Personal assets and characteristics}

Personal characteristics. Interviewees found that personal characteristics are one of the most important factors affecting spin-off creation from student satellite projects. Students who are more determined, motivated and more conscious of their daily tasks also tend to be more entrepreneurial. It was outlined, for example, by one of the interviewees that, after graduation, he made an aware choice to continue to learn and absorb industry related knowledge relevant to his professional growth - as a sign of making conscious and determined choices:

"I think it depends on the person. I, for example, made a conscious choice in 2011, that, umm, when I go home in the evening, I won't open Postimees.ee [Estonian news portal] and start scrolling there, doing 
nothing/.../ for example, I consume news sources like Hackernews [news portal] that belongs to Y-Combinator which deals with start-ups and rest of the related stuff. If you do that all the time, something will stick.”

Also, readiness to gain knowledge and learn was considered an important personal trait in terms of entrepreneurial behaviour among students: 'It doesn't really matter if one has a technical background or a non-technical background. People who officially have a nontechnical background can understand technical aspects very well." Therefore, personal characteristics are very important when it comes down to entrepreneurial behaviour among students, especially in terms of being ready to go the extra mile and explore additional professional opportunities.

Student's role in the project. Secondly, the role of students involved in the project was emphasised. Students who are more likely to create spin-offs are also the ones who take leading roles in projects. This does not only apply to leading teams, but also to executing tasks related to project management - hiring or involving new members, organising meetings, and taking ownership and responsibility for getting things done. Student satellite projects provide a great platform for students to take this kind of initiative. It was also mentioned by one of the interviewees that taking this position in student satellite project felt as a natural step for him: "My role in the project changed to a managing function. It was natural for me, doing that for years, and it wasn't a big change for me to have a management position in the company." Taking such roles in student technology projects usually indicates that students possess a wider understanding of technology that is being developed within these projects and of the benefit it brings. For instance, one of the interviewees said that the ones more likely to start companies are not usually the best specialists, but they possess better knowledge of the overall impact that the technologies being developed could provide. "And, usually, these guys [members of the student satellite project] are not the best electronics designers, but they are more like generalists who can do electronics too, if they want to. They also see the bigger picture and know how to make people work." Therefore, a student's role in these projects is also an important factor in terms of spin-off creation. Students who fulfil leading roles in the project are usually more likely to create spin-offs from student satellite projects. 
Organisation's role in student's personal growth. It was outlined that organisations can have a significant impact on students' personal growth, and thereby facilitate the creation of spin-offs. In order to do that, organisations should support students by giving them enough freedom to act and teaching them to make independent decisions. One of the interviewees, for example, stated that it is important to teach students to recognise problems, not just to figure out solutions. "In ESTCube-1 we had a specific task - to build a satellite. Everyone had to do something of their own speciality, but we had to understand what it exactly was that we had to do." Nevertheless, it was also mentioned that, when it comes to giving students freedom to act, the role of organisations is to keep an eye on the project and make relevant decisions, if needed. This would make it possible to move forward with projects and not become stuck in certain phases. One of the interviewees outlined that the lack of decision making power was a limitation for one of the satellite projects that he was part of. “... that was a drawback - there should have been one person, who had previously engineered the system, to make sure that everyone was doing their part." The lack of decision making power at the time derived from the lack of experience among students and other members involved in the project. Factors related to human capital are discussed under the next category. Student satellite projects can have a significant role in the organisational aspect of students' personal growth and, consequently, the encouragement of entrepreneurial behaviour.

\subsection{Knowledge related assets}

Human capital. Human capital was also mentioned as an important aspect in terms of technology. Interviewees noted that one of the main factors having an impact on spin-off creation is the human capital involved in satellite projects. In order to have more innovative projects, people with more knowledge in the industry need to be involved in these projects. Nevertheless, members of student satellite projects who were interviewed were of the opinion that Estonia and Finland are currently still limited in terms of the critical mass of experienced people in space industry community. For example, it was directly stated by one of the interviewees as a factor restraining innovation:

\footnotetext{
"If you want to do it in a small country like Estonia or Finland, where no one has ever done anything like this, and you don't have anyone to
} 
ask for help /.../ ... you need to have this sort of critical mass of people who know how to develop these things."

The possession of previous experience is important for the growth of projects themselves as well. It was mentioned by one of the interviewees that this has a direct impact on the sustainability of projects:

\footnotetext{
"They should not start from zero though. They should learn from the previous project. /.../ During that time, when the third guy is stepping aside from the project, the new guy should have already introduced the project to the new guy".
}

One of the interviewees said that the more people with previous experience are involved in the projects, the more chance there is for innovation - in such case, all students would not have to start from the basics and some of them could work on more innovative projects.

\footnotetext{
"And what's common for both - Formel [Formula Students Team Tallinn] and the robots club [Tallinn University of Technology Robots Club] - is that every year some people start from the basics, some continue others' work and some start with new projects."
}

Seeing other students working on more advanced projects can also be motivating for new members who are still learning the basics. The importance of creating such synergy between different projects within the university and its impact on sharing ideas was directly pointed out by one of the interviewees as well:

"...then I get ICEYE and Aalto-1 to share ideas in order to mix and see what others are doing and what we are doing, and then the most talented ones jump to ICEYE where there are already people like them who already do something like that, and they can work in synergy."

Thus, in terms of innovation, more experienced people as human capital needs to be involved in these projects. However, as the evolvement of this kind of human capital takes time, it is a limitation for smaller space technology communities like there are in Estonia 
and Finland. Student satellite projects are currently filling this gap in the industry to educate the critical mass of people experienced in space technology development.

One of the main limitations is time. Students usually participate in these projects within the timeline of their studies in the university. In terms of space technology development, this is a critical limitation, as the duration of their studies is too short to provide students with the experience needed for innovation. This was directly related to the technology developed in the course of the project. As students become more experienced over time, they need more challenging projects to stay motivated, but, at the same time, they have to finish their studies. This aspect was also mentioned by one of the interviewees:

\section{"In the case of a training project, it is very difficult to manage or coordinate people, because you want them to receive their diploma within two years, not to stay drawing the circuit for two years, and then they draw again, and that's not quite right."}

With regard to innovation, more experienced people need to be involved in projects or be trained through sustainable growth during student satellite projects.

Project objectives. The importance of involving more advanced innovative objectives in projects was also mentioned as one of the key factors in terms of spin-off creation - this is where the innovation is coming from. Nevertheless, there was a strong agreement that student satellite projects should remain educative since the primary aim of these projects is to provide students with relevant education. One of the interviewees summarised this as follows: "The idea behind building a satellite should not be doing science but teaching students." In connection with innovation, it was also mentioned that the capabilities of educational student satellite projects have reached their limits, meaning that there is not much innovative in the industry that these projects could contribute to. Therefore, student satellite projects are educational in essence, and, as an objective, this discourages the growth of innovation.

The impact that educational student satellite projects have on innovation is mostly connected to the distribution of new ideas in the course of the project through the development process of the satellite. It was mentioned that if the main objective of the 
project is to test new ideas, it would be wise to save time and find resources to do as little by yourself as technologically possible. This means that it would be rational to buy a fully developed satellite or assemble it from pre-manufactured subsystems. One of the interviewees described it as follows: "If we have a technological idea that we want to test, we are interested in testing it in comparison with some subsystem. If this thing works now, we are no longer interested in educating students but, instead, in testing the idea." The bespoke approach to satellite development, in the case of which all subsystems are developed from scratch, provides the best platform for the growth of innovative ideas. This is also the most common development method used in student satellite projects. It was outlined by one of the interviewees that this development methods fulfils the goal of teaching students to recognise problems related to the industry, and it was also mentioned as a factor under the organisation's role in student's personal growth. "If you do it on your own from scratch, or, well, if you are trying to do it on your own in the most part, the team learns more, and when starting a company, the team learns more. /.../ If they see problems arising from the hardware development process, and if you want to make something that works, and there is so much that needs to be done, then it is not that simple." The bespoke approach to development also fulfils the objective of using the most recent technology in satellites as an important factor in terms of innovation, which was described by one of the interviewees: “....as technology develops so fast, of course you can be innovative if you make it by yourself, and use new components that have not been used before..." Therefore, in terms of coming up with new innovative ideas, student satellite projects are highly beneficial since they teach students to recognise pain points in the industry, and lead to new ideas. In order to test more advanced ideas, however, satellites also need to be more advanced.

\subsection{Intellectual property related assets}

Ownership. Categories that stood out among topics discussed under the protection of intellectual property were transparency and ownership. It was agreed that all methods used along with the protection of IP should facilitate the execution of innovative ideas. Even though there were different opinions as to the ownership of IP, the overall assumption was that, regardless of who is the owner of IP, no organisation or individual should have the right to hinder the execution of a good idea or take advantage of it. One 
of the interviewees said that universities can have a significant role in helping student spin-offs grow:

\begin{abstract}
"If the biggest technological university in Finland has spent four years on building a satellite, and has developed several technologies just based on that, and now hands the whole package over to a small company that will continue the development work, it sounds far more exciting than just four boys saying that we have built something. "
\end{abstract}

Therefore, the purpose of the methods used to protect intellectual property should support innovation in order to encourage the creation of spin-offs.

Transparency. The purpose of the use of IP was directly related to the transparency of methods used to protect intellectual property. Lack of transparency can bring along conflicts and misunderstandings: "If everything belongs to the university, and the university could start demanding something from you, it is really not okay." Students have to understand which issues related to intellectual property protection could arise in the future and how these could be handled. Yet, students usually lack knowledge related to issues concerning IP, and this is something where both - universities and student satellite projects - should take action and provide relevant knowledge to students. Transparency in terms of the protection of intellectual property could also prevent conflicts and misunderstandings between the university and students. Relevant additional training could be a tool to achieve that.

\title{
4.4. Social capital related assets
}

Interdisciplinarity. One of the main factors encouraging the creation of spin-offs mentioned was social capital hidden in projects themselves. The fact that projects involve students from different disciplines does encourage the creation of spin-offs by creating a network of like-minded people. This is very important for knowledge sharing and future professional contacts.

Support from the university. It was also mentioned that the support received from the university and student satellite projects themselves can be important. At the same time, half of the interviewees mentioned that they did not receive any support or 
acknowledgement from student satellite project management or their university. These entrepreneurs also did not turn to internal resources within the university related to the student satellite project to obtain business knowledge or anything else needed for spinoff establishment. The ones who did, however, received substantial help.

Each category discussed during the analysis of the interviews presented factors that encourage the creation of spin-offs from student satellite projects. The summary of these factors is presented in Table 3. In the following section, the findings are compared and discussed in a theoretical context.

Table 3. Factors encouraging the creation of spin-offs from student satellite projects

\begin{tabular}{|c|c|}
\hline CATEGORY & $\begin{array}{c}\text { FACTORS ENCOURAGING THE CREATION } \\
\text { OF SPIN-OFFS }\end{array}$ \\
\hline Personal characteristics & $\begin{array}{l}\text { Entrepreneurial characteristics, eagerness to learn, } \\
\text { motivation. }\end{array}$ \\
\hline Student's role in the project & $\begin{array}{l}\text { Initiative to take more leadership and project } \\
\text { management related roles in the project. }\end{array}$ \\
\hline Organisation's role in student's personal growth. & $\begin{array}{l}\text { Taking action to encourage the personal growth of } \\
\text { students by providing freedom to make decisions } \\
\text { and act. }\end{array}$ \\
\hline Human capital & $\begin{array}{l}\text { Continuing the provision of education in order to } \\
\text { create the critical mass of space technology } \\
\text { specialists needed for innovation. } \\
\text { Supporting the sustainability and evolvement of } \\
\text { more advanced projects. }\end{array}$ \\
\hline Project objectives & $\begin{array}{l}\text { Educational projects provide a good platform for } \\
\text { the development of innovative ideas. } \\
\text { In order to test innovative ideas, more advanced } \\
\text { technologies are needed. }\end{array}$ \\
\hline Ownership of IP & Using methods that support innovation. \\
\hline Transparency of IP protection & $\begin{array}{l}\text { Transparency of regulations and additional } \\
\text { education provided. }\end{array}$ \\
\hline Interdisciplinarity & $\begin{array}{l}\text { The interdisciplinary nature of student satellite } \\
\text { projects encourages the creation of spin-offs. }\end{array}$ \\
\hline Support from the university & $\begin{array}{l}\text { Business and industry related support from the } \\
\text { university and the projects, as well as } \\
\text { acknowledgement. }\end{array}$ \\
\hline
\end{tabular}




\section{Discussion}

The aim of this thesis was to determine which factors encourage the creation of spin-offs from student satellite projects. In the following discussion, four main topics were treated, comparing the findings of this study with results from previous literature. The topics related to factors encouraging the creation of spin-offs derived from the resource-based view of the firm. Previous research has concentrated mainly on these aspects from the point of view of a scientist as an entrepreneur. The findings of this study concentrated on the impact of those factors among students.

The first topic to be discussed is personal assets and characteristics. In the course of previous research, it has been found that personal characteristics related to entrepreneurial behaviour have a significant impact on the creation of spin-offs from universities. Characteristics outlined in previous literature, such as the need for independence and achievements, were considered important aspects in terms of the creation of spin-offs by scientists, being directly related to their experience and career. The findings, on the other hand, concentrated on students and the personal characteristics mentioned were mostly related to personal growth - determination, self-awareness in daily decisions, eagerness to learn, and motivation for self-improvement. Additionally, findings demonstrated that students who show more initiative by taking leadership or project management related roles in student satellite projects also tend to be more entrepreneurial than others. This indicates that self-growth at the time of being involved in student satellite projects is considered more important than a sudden change in the career path by students. This also stems from the fact that students value the learning outcome, rather than the practical implementation of previously acquired experience. This also correlates with the results of the theory, in the case of which it has been found that even if venture creation fails, students appreciate the experience gained. Scientists, on the other hand, seek to add direct additional value to their professional career. The findings also showed that organisations can have an impact by helping students grow within these projects, providing them with enough freedom to act, and teaching them to identify problems, take responsibility and make decisions. Therefore, personal characteristics encouraging the creation of spin-offs among students are related to self-growth, referring to a competitive advantage in life and 
one's future professional career. The creation of spin-offs among scientists is more related to the need for professional achievements.

From the knowledge related aspect, the involvement of more experienced and qualified human capital can encourage the upspring of innovative ideas and the creation of spinoffs. This also applies to technology developed within student satellite projects - in order to have a stronger impact in terms of innovation, satellites currently developed under student satellite projects need to become more advanced. The findings also confirmed the importance of the engagement of more experienced human capital that would have the knowledge to contribute into building these advanced technologies. Student satellite projects themselves are too basic to contribute in terms of innovation, and they usually lack the presence of or access to relevant human capital. It was based on two aspects. First, innovation in space technology industry takes time. And currently this limitation as student's involvement in the projects is just too short. The experience of interviewees was based on projects that were among the first initiatives to start offering direct space technology related education in Estonia and Finland. Therefore, the lack of previous critical mass of experienced people in carrying out space technology related projects was considered a significant limitation to the creation of spin-offs and innovation. Supporting space technology related educative initiatives helps to create this critical mass of experienced specialists in the industry, and, within these projects, extend the possibilities for innovative initiatives in the future. Furthermore, the evolvement of more advanced knowledge within these projects is also considered vital in terms of the sustainable growth of student satellite projects as it facilitates the development of more advanced initiatives within the projects. This would also contribute on the issue of limited timeframe of student's involvement in the projects. Similarly, to previous research, the findings of this study confirmed that development methods currently used in student satellite projects the bespoke approach to development - have proved to be highly beneficial for innovation. In addition to technological advantages, this method is also considered the best for the development of new ideas and identifying the pain points of the industry. From the technological aspect, thus, student satellite projects provide a great platform for future innovative ideas. With the resources available today, the support for current educative student satellite projects can be considered a factor enhancing innovation, as it 
creates the experience and knowledge needed to encourage the creation of spin-offs in the future.

Even though the ownership of intellectual property has received great attention in previous research as one of the main metrics for measuring the extent of innovation, it does not have a very strong effect on the encouragement of spin-off creation among students. Similarly to previous research, the findings of this study confirmed that the preferences of students in terms of protecting intellectual property are strongly related to activities aimed at supporting innovation, and not determining the actual ownership, and this encourages the creation of spin-offs. The main idea behind this is that no individual or organisation should have the right to restrain the implementation of innovative solutions. This was also related to the transparency of how intellectual property is regulated. One of the current drawbacks in these projects is that students are not fully aware of the aspects related to IP protection within universities or student satellite projects, meaning that additional training in this field could be highly beneficial in terms of encouraging the creation of spin-offs and ensuring transparency. Therefore, additional training and information sharing in connection with IP protection by universities and student satellite projects would help to encourage students to be more innovative. In that respect, universities and student satellite projects are considered to play an important role.

Social capital has been deemed to have a substantial impact on innovation. Previous research has found that the presence of knowledge from different disciplines is very important for high-tech industries such as space technology - particularly in terms of technical knowledge. The findings confirmed that students consider the multi-disciplinary nature of student satellite projects one of the greatest advantages, as it helps to create the necessary industry related social network among students. Other external and internal contacts are also considered very important to encourage the creation of spin-offs. Yet, this study showed that students do not tend to make any efforts to search for help within these projects. Therefore, the initiative to provide additional support should come from projects or universities themselves.

Even though the creation of spin-offs in universities has received great attention, there has been less research on spin-offs created by students. This study aims to fill this gap by concentrating on a special learning platform implemented in universities - student 
satellite projects. It was found that, compared to scientists, the impact of the presence of additional knowledge under all four topics covered in this thesis was considered far more important than specific activities needed for the creation of spin-offs among scientists. This means that the inclination of students towards entrepreneurship in the wider sense, i.e. being entrepreneurial instead of being an entrepreneur, is more extensive as compared to scientists. Table 3 outlines the main findings related to factors encouraging the creation of spin-offs among students.

Table 3. Findings related to factors encouraging the creation of student-founded spin-offs from student satellite projects

\begin{tabular}{|l|l|}
\hline \multicolumn{1}{|c|}{ TOPIC } & \multicolumn{1}{|c|}{ FINDINGS } \\
\hline $\begin{array}{l}\text { Personal assets and } \\
\text { characteristics }\end{array}$ & $\begin{array}{l}\text { Entrepreneurial characteristics of students are more related to personal } \\
\text { growth as a beneficial advantage for the future, as opposed to } \\
\text { entrepreneurial characteristics of scientists who tend to concentrate more } \\
\text { on direct achievements in their professional career. Organisations can } \\
\text { have a significant impact in terms of encouraging students to develop } \\
\text { these characteristics. }\end{array}$ \\
\hline Knowledge related assets & $\begin{array}{l}\text { Supporting educative student satellite projects along with the growth of } \\
\text { the critical mass of experienced people needed in the industry and within } \\
\text { the projects is currently a limitation to innovation stemming from student } \\
\text { satellite projects. }\end{array}$ \\
\hline IP related assets & $\begin{array}{l}\text { Additional training and information sharing concerning IP within student } \\
\text { satellite projects or universities are more important for encouraging spin- } \\
\text { off creation than specific regulations. }\end{array}$ \\
\hline $\begin{array}{l}\text { Social capital related } \\
\text { assets }\end{array}$ & $\begin{array}{l}\text { Social contacts between students from different disciplines has a } \\
\text { significant effect on the creation of spin-offs. } \\
\text { Organisational initiatives within universities and student satellite projects } \\
\text { to encourage students to create spin-offs can have a substantial effect on } \\
\text { innovation originating from these projects. }\end{array}$ \\
\hline
\end{tabular}

\section{Conclusion}

The objective of the thesis was to see how the spin-off creation from student satellite projects could be encouraged. The creation of spin-offs by students in high-tech industries has received little attention in previous research. With the implementation of new learning methods in universities and the growing importance of innovation in high-tech industries, 
research conducted on students' entrepreneurship within these industries has become more relevant. It was found that current limitations on innovation upspring among students in space technology are still significant. This study also showed that current limitations on the creation of innovation among students in space technology are still considered highly restraining. This mostly stems from the advanced level of knowledge needed in the industry which is considered limited by students as well as the whole community. Relevant support, however, can have a significant impact in terms of inspiring students to be more entrepreneurial and creating an environment for the growth of spin-offs in the future. Therefore, space technology related educative initiatives should be considered rather as a marathon not a sprint, where resources for immediate success are currently scarce, but in the long run can become highly beneficial. The success depends on the continues knowledge distribution within the projects itself and to subsequent projects involved. In terms of student entrepreneurship and innovative hightech market growth, student technology projects could offer a valuable input.

The study concentrated on four main themes - personal assets and characteristics, knowledge related assets, IP protection related assets and social capital related assets. Nevertheless, for further studies, more business development and organizational support related determinants could be involved in the study. Also, as the topic has not received wide attention, case studies about specific spin-offs that have already evolved from student satellite projects, would be advisable in the future. Similar studies on different student technology projects relevant to other high-tech industries, should also be involved in these studies. This would help to understand the dynamical differences between the industries. 


\section{References}

Åstebro, T., Bazzazian, N., \& Braguinsky, S. (2012). Startups by recent university graduates and their faculty: Implications for university entrepreneurship policy. Research Policy, 41(4), 663-667.

Barney, J. (1991). Firm Resources and Sustained Competitive Advantage. Journal of Management, 17(1), 99-120.

Baron, R. (2007). Entrepreneurship: A Process Perspective. In J. Baum, J. Baum, M. Frese, \& R. Baron (Eds.), The Psychology of Entrepreneurship (pp. 19-40). East Sussex: Lawrence Elbraum Associates, Inc.

Berk, J., Straub, J., \& Whalen, D. (2013). The Open Prototype for Educational NanoSats: Fixing the Other Side of the Small Satellite Cost Equation. Aerospace Conference Big Sky: IEEE, 1-16.

Beyhan, B., \& Findik, D. (2018). Student and graduate entrepreneurship: ambidextrous universities create more nascent entrepreneurs. The Journal of Technology Transfer, 43(5), 1346-1374.

Boh, W., De-Haan, U., \& Strom, R. (2016). University technology transfer through entrepreneurship: faculty and students in spinoffs. The Journal of Technology Transfer, 41(4), 661-669.

Bryant, A., \& Charmaz, K. (2019). Deductive Qualitative Analysis and Grounded Theory: Sensitizing Concepts and Hypothesis-Testing. In A. Bryant, \& K. Charmaz, The SAGE Handbook of Current Developments in Grounded Theory (pp. 107-120). London: SAGE Publications Ltd.

Buchen, E. (2015). Small Satellite Market Observations. Small Satellite Conference (pp. 1-5). Utah: AIAA/Utah State University.

Cooper, A. (1971). Spin-Offs and Technical Entrepreneurship. IEEE Transactions on Engineering EM-18(I), 2-6. 
Donnelly, R., \& Fitzmaurice, M. (2005). Collaborative Project-based Learning and Problem-based Learning in Higher Education: a Consideration of Tutor and Student Role in Learner-Focused Strategies. In G. O'Neill, S. Moore, \& B. McMullin, Emerging Issues in the Practice of University Learning and Teaching (pp. 87-98). Dublin: AISHE/HEA.

Dubos, G. (2010). Statistical reliability analysis of satellites by mass category: Does spacecraft size matter? Acta Astronautica, 67(5-6), 584-595.

Etikan, I., S. A. Musa, \& Alkassim, R. (2016). Comparison of Convenience Sampling and Purposive Sampling. American Journal of Theoretical and Applied Statistics, $5(1), 1-4$.

Fini, R., Fu, K., Mathisen, M., Rasmussen, E., \& Wright, M. (2017). Institutional determinants of university spin-off quantity and quality: a longitudinal, multilevel, cross-country study. Small Business Economics, 48(2), 361-391.

Gibbs, G. (2007). The Nature of Qualitative Analysis. In G. Gibbs, Analyzing Qualitative Data (pp. 1-8). London: SAGE Publications Ltd.

Goldfarb, B., \& Henrekson, M. (2003). Bottom-up versus top-down policies towards the commercialization of university intellectual property. Research Policy, 32(4), $639-658$.

Guba, E., \& Lincoln, Y. (2004). Distinguishing Qualitative Research. In S. Hesse-Biber, \& P. Leavy, Approaches to Qualitative Research (pp. 1-16). Oxford: Oxford University Press.

Hayter, C. (2016). Constraining entrepreneurial development: A knowledge-based view of social networks among academic entrepreneurs. Research Policy, 45(2), 475490.

Hayter, C., Lubynsky, R., \& Maroulis, S. (2017). Who is the academic entrepreneur? The role of graduate students in the development of university spinoffs. The Journal of Technology Transfer, 42(6), 1237-1254. 
Helm, R., \& Mauroner, O. (2007). Success of research-based spin-offs. State-of-the-art and guidelines for further research. Review of Managerial Science, 1(3), 237-270.

Hevner, R., Holemans, W., Puig-Suari, J., \& Twiggs, R. (2011). An Advanced Standard for CubeSats. Annual AIAA/USU Conference on Small Satellites (pp. 1-12). Logan: AIAA/USU.

Karvinen, K., Tikka, T., \& Praks, J. (2015). Using Hobby Prototyping Boards and Commercial-off-the-shelf (COTS) Components for Developing Low-cost, Fastdelivery Satellite Subsystems. Journal of Small Satellites, 4(1), 301-314.

La Regina, V. (2013). Benefits of Interdisciplinary Concept for Post-Graduate Space Programs. 64th International Astronautical Congress 2013 (pp. 1-6). Beijing: International Astronautical Federation.

Lackeus, M. (2015). Entrepreneurship in Education. What, Why, When, How. Entrepreneurship 360: Background paper, 6-45.

Landry, R., Amara, N., \& Rherrad, I. (2006). Why are some university researchers more likely to create spin-offs than others? Evidence from Canadian universities. Research Policy, 35(10), 1599-1615.

Li, Z., Seering, W., Ramos, J., Yang, M., \& Wallace, D. (2017). Why Open Source?: Exploring the Motivations of Using an Open Model for Hardware Development. ASME 2017 International Design Engineering Technical Conferences and Computers and Information in Engineering Conference (pp. 1-9). Cleveland: ASME International.

Lilleväli, U., \& Täks, M. (2017). Competence Models as a Tool for Conceptualizing the Systematic Process of Entrepreneurship Competence Development. Education Research International Volume 2017, 1-16.

Marion, T., Dunlap, D., \& Friar, J. (2012). The university entrepreneur: acensus and survey of attributesand outcomes. R\&D Management, 42(5), 401-419. 
Mathisen, M., \& Rasmussen, E. (2019). The development, growth, and performance of university spin-offs: a critical review. The Journal of Technology Transfer, 1-48.

Miranda, F., Chamarro, A., \& Rubio, S. (2018). Re-thinking university spin-off: a critical literature review and a research agenda. Journal of Technology Transfer, 43(4), 1007-1038.

OECD. (2016). New trends in space innovation. In OECD, Space and Innovation (pp. 1336). Paris: OECD.

Okudan, G., \& Rzasa, S. (2006). A project-based approach to entrepreneurial leadership education. Technovation, 26(2), 195-210.

OSHWA. (2019). Definition (English). Retrieved from Open Source Hardware Association Web site: https://www.oshwa.org/definition/

Pirnay, F., Surlemont, B., \& Nlemvo, F. (2003). Toward a Typology of University Spinoffs. Small Business Economics, 21(4), 355-369.

Pisano, G., Teece, D., \& Shuen, A. (1997). Dynamic capabilities and strategic management. Strategic management journal, 18(7), 509-533.

Poghosyan, A., \& Golkar, A. (2017). CubeSat evolution: Analyzing CubeSat capabilities for conducting science. Progress in Aerospace Sciences, 88, 59-83.

Powers , J., \& McDougall, P. (2005). University start-up formation and technology licensing with firms that go public: a resource-based view of academic entrepreneurship. Journal of Business Venturing, 20(3), 291-311.

Rao, B., \& Mulloth, B. (2017). The Role of Universities in Encouraging Growth of Technology-Based New Ventures. International Journal of Innovation and Technology Management, 14(4), 1-22.

Rasmussen, E., \& Wright, M. (2015). How can universities facilitate academic spin-offs? The Journal of Technology Transfer, 40(5), 782-799. 
Rodrı'guez, J., Laverón-Simavilla, A., del Cura, J., \& Ezquerro, J. (2015). Project Based Learning experiences in the space engineering education at Technical University of Madrid. Advances in Space Research, 56(7), 1319 - 1330.

Shane, S., \& Venkataraman, S. (2000). Entrepreneurship as a Field of Research. The Academy of Management Review, 25(1), 217-226.

Sohn, S., \& Han, E. (2019). Engineering graduate students' views on the effective ownership of academic patents. The Journal of Technology Transfer, 44(1), 132154.

Souitaris, V., Zerbinati, S., \& Al-Laham, A. (2007). Do entrepreneurship programmes raise entrepreneurial intention of science and engineering students? The effect of learning, inspiration and resources. Journal of Business Venturing, 22(4), 566591.

Straub, J., Marsh, R., \& Whalen, D. (2017). To Build, Buy, or in Between? In J. Straub, R. Marsh, \& D. Whalen, Small Spacecraft Development Project-Based Learning (pp. 37-52). Springer International Publishing.

Straub, J., Marsh, R.-A., \& Whalen, D. (2017). Why Start a Small Spacecraft Program. In J. Straub, R.-A. Marsh, \& D. Whalen, Small Spacecraft Development ProjectBased Learning - Implementation and Assessment of an Academic Program (pp. 21-35). Cham: Springer International Publishing AG.

Sundaramoorthy, P., \& Cervone, A. (2013). How Can a Group of 3rd Year University Students Design a Real Nano-Satellite? A Case Study at Delft University of Technology. 64th International Astronautical Congress (pp. 1-12). Beijing: International Astronautical Federation.

Swartwout , M., \& Jayne, C. (2016). University-Class Spacecarft by the Numbers: Success, Failure, Debris. (But Mostly Success.). Technical Session XIII: Education (pp. 1-18). Utah: Small Satellite Conference.

Sweeting, M. (2018). Modern Small Satellites - Changing the Economics of Space. Proceedings of the IEEE (pp. 342-361). Guildford: IEEE. 
Täks, M., Tynjälä, P., Toding, M., Kukemelk, H., \& Venesaar, U. (2014). Engineering Students' Experiences in Studying Entrepreneurship. Journal of Engineering Education, 103(4), 573-598.

Thomas, D. (2006). A General Inductive Approach for Analyzing Qualitative Evaluation Data. American Journal of Evaluation, 27(2), 237-246.

Urbano, D., \& Guerrero, M. (2013). Entrepreneurial Universities: Socioeconomic Impacts of Academic Entrepreneurship in a European Region. Economic Development Quarterly, 27(1), 40-55.

Vestergaard, L. (2015). Entrepreneurship in Education in the Baltic Sea Region. EU Strategy for the Baltic Sea Region. Copenhagen: Danish Ministry of Education and Danish Foundation for Entrepreneurship.

Vohora, A., Wright, M., \& Lockett, A. (2004). Critical junctures in the development of university high-tech spinout companies. Research Policy, 33(1), 147-175.

Wood, M. (2011). A Process Model of Academic Entrepreneurship. Business Horizons, 54(2), 153-161.

Wright, M., Siegel, D., \& Mustar, P. (2017). An emerging ecosystem for student startups. The Journal of Technology Transfer, 42(4), 909-922. 


\section{Appendix 1}

Interview questions

Author: Triin Teppo

Name of the interviewee: NAME

Introduction to the interview: the aim of the thesis is to study which factors could encourage the creation of spin-offs from student satellite projects. Interviews are carried out with members of student satellite projects who have founded companies during or after their involvement in student satellite projects. It is possible to remain anonymous.

\section{Background questions}

1. What was your role in the student satellite project?

- Did your role change over time?

- Was this your first contact with space technology development?

2. What was the name of the company that you founded and what did it specialise in?

- What did it have in common with the student satellite project?

\section{Social capital assets}

1. Why did you join the student satellite project?

- Did these objectives change over time?

- Was this your first contact with space technology?

2. How important is the multi-disciplinary nature of student technology projects and the involvement of students from different specialities in your opinion?

- How much does it encourage the creation of spin-offs?

3. What was the involvement of the management in creating your company?

- How important do you think it is in terms of the creation of spin-offs?

4. How much business-related know-how did you receive during your time in the student satellite project and in the university?

- Is this important? 


\section{Knowledge related assets}

1. Can you provide a brief description of the technological beginning of your company?

2. How were the technologies developed on the satellite related to technologies developed in your company?

3. What kind of technological objectives should student satellite projects fulfil?

- Which of them would be the most beneficial in encouraging the creation of spinoffs?

4. What kind of technology development method would you recommend for student satellite projects - bespoke approach versus kit-based approach?

- Which of the methods would be the best for encouraging the creation of spin-offs?

\section{Intellectual property assets}

1. Were there any issues during the satellite project related to intellectual property protection?

2. How should intellectual property protection be handled in student satellite projects?

- How could it encourage the creation of spin-offs?

\section{Additional questions}

1. Would you like to add anything in terms of how to encourage the creation of spinoffs from student satellite projects? 


\section{Non-exclusive licence to reproduce thesis and make thesis public}

\section{I, Triin Teppo}

(date of birth: 29.05.1990)

1. herewith grant the University of Tartu a free permit (non-exclusive licence) to:

1.1. reproduce, for the purpose of preservation and making available to the public, including for addition to the DSpace digital archives until expiry of the term of validity of the copyright, and

1.2. make available to the public via the web environment of the University of Tartu, including via the DSpace digital archives until expiry of the term of validity of the copyright,

„Factors encouraging the creation of spin-offs from student satellite projects“,

supervised by Eneli Kindsiko and Tõnis Eerme

2. I am aware of the fact that the author retains these rights.

3. I certify that granting the non-exclusive licence does not infringe the intellectual property rights or rights arising from the Personal Data Protection Act.

Tartu, 23.05.2019 